\title{
DEBIUTY
}

LIDIA KURCIŃSKA

Wydział Nauk Pedagogicznych

Akademia Pedagogiki Specjalnej im. M. Grzegorzewskiej

Warszawa

Forum Pedagogiczne 2018/2

Wpłynęło: 03.04.2018

Zatwierdzono do druku: 26.09.2018

ORCID ID: http://orcid.org/oooo-0oo2-9531-9633

DOI: $10.21697 / \mathrm{fp} .2018 .2 .18$

\section{HETEROTOPIA PRZEDSZKOLA, O „NIE-MIEJSCU W MIEJSCU”}

Streszczenie: Są miejsca, które tworzą własne rytuały, a okoliczności nadają im funkcje. Przedszkole wydaje się być takim miejscem - „inna przestrzenią”. Celem moich rozważań, podczas których ulokowałam rozumienie specyficznej przestrzeni przedszkola jako „nie-miejsca w miejscu”, uczyniłam sześć zasad definiujących heterotopię Foucaulta. Analizując każdą z nich odnoszę się do przedszkola jako instytucji, która poza realizacją swoich podstawowych celów, skoncentrowanych na opiece i wspomaganiu rozwoju dziecka, staje się unikalnym mikroświatem dla każdego wychowanka.

Słowa kluczowe: heterotopia, Michel Foucault, przedszkole.

\section{Wstęp}

Michel Foucault w wygłoszonym przez siebie wykładzie „Of other space” sugeruje, że istnieją pewne przestrzenie, które są poza wszelkimi miejscami, nawet jeżeli możliwe jest wskazanie ich rzeczywistej lokalizacji (Foucault 1984). Te „inne przestrzenie”, jak wyjaśnia Foucault, stanowią część społeczeństwa, zarezerwowane są dla konkretnych osób, w nich zasady i obrzędy mogą różnić się od tych w miejscach publicznych.

Etymologiczne źródło pochodzenia pojęcia heterotopii pozwala na uzyskanie większej jasności znaczeniowej. Greckie topos bowiem to „miejsce, okolica”; heteros tłumaczy się jako „inny, różny”. Heterotopia zatem to miejsce inne, różne, różnorodne. Aby zrozumieć heterotopię, należy jej wyjaśnienie uzupełnić, zestawiając ją $\mathrm{z}$ utopią, która rozumiana jest jako nie-miejsce, miejsce nieistniejące fizycznie, gdyż z greckiego ou-topos znaczy „utopia”. To właśnie utopia powoduje, że heterotopia może istnieć, umożliwia jej istnienie i bytowanie; wyznacza jej ontologię (Mendel 2017). Za Marią Mendel możemy przytoczyć słowa M. Foucaulta: „są, prawdopodobnie w każdej kulturze, w każdej cywilizacji, miejsca (lieux) 
rzeczywiste - miejsca, które wyznaczane są wraz z tworzeniem się społeczeństwa, które są czymś w rodzaju kontr-miejsc (contre-emplacements), rodzajem efektywnie odgrywanej utopii, w której wszystkie inne rzeczywiste miejsca (emplacements), jakie można znaleźć w ramach kultury, są jednocześnie reprezentowane, kontestowane i odwracane" (Mendel 2017, s. 139, za: Foucault 2005, s. 118-120). M. Foucault opisuje heterotopię w doświadczeniu lustra - spoglądając w nim na siebie, jesteśmy jednocześnie tu i tam. Mentalna i fizyczna przestrzeń spotykają się w tym spojrzeniu (Mendel 2009). W artykule Heleny Ostrowickiej czytamy, że M. Mendel w swojej pracy traktuje heterotopię jako „miejsce rzeczywiste” - konstrukcję przestrzeni w sieci relacji i krzyżujących się ludzkich „spojrzeń”. Stąd też heterotopologia proponowana przez M. Foucaulta jest opisem społecznych relacji (Ostrowicka 2010).

Każda kultura tworzy własne heterotopie. Celem tego artykułu jest przybliżenie jednej z nich - przedszkola, którą spostrzegam jako „inną przestrzeń”, „nie-miejsce” w miejscu. Chciałabym się zastanowić, w jaki sposób przedszkole może się odnosić do heterotopii Foucaulta.

Foucault przedstawia sześć zasad definiujących „inne przestrzenie”:

1. Są zarezerwowane dla osób w kryzysie lub dewiacji;

2. Ich historia ma wpływ na ich funkcję;

3. Powstają z zestawionych ze sobą przestrzeni;

4. Są powiązane $\mathrm{z}$ „kawałkami” czasu;

5. Są to systemy zamknięte;

6. Mają związek z szerszym społeczeństwem (Blair 2009).

\section{Pierwsza zasada}

Foucault sugeruje, że nie ma prawdopodobnie ani jednej kultury na świecie, która nie stanowi heterotopii. To jest stała każdej ludzkiej grupy (Foucault 1984). Foucault mówi, że nie ma uniwersalnej postaci heterotopii, możemy jednak podzielić je na dwie główne kategorie: heterotopie kryzysowe i heterotopie odchylenia. Heterotopie kryzysowe „zarezerwowane są dla osób, które w odniesieniu do społeczeństwa i środowiska ludzkiego, w którym żyją, znajdują się w stanie kryzysu: nastolatkowie, kobiety miesiączkujące, kobiety w ciąży, osoby starsze itp.”. Heterotopie odchylenia natomiast to miejsca, gdzie znajdują się „osoby, których zachowanie jest niezgodne z wymaganą średnią lub normą" (Foucault 1984, s. 4-5).

Przedszkole wydaje się spełniać pierwszą zasadę Foucaulta, stanowiącą o heterotopii. Dziecko postawione pierwszy raz w sytuacji, która może być postrzegana jako stan zagrożenia naruszającego symbiotyczną więź z matką, sytuacji mogącej wywołać stany emocjonalne objawiające się tzw. lękiem separacyjnym, spowodowanym obawami przed długotrwałą rozłąką, jest w stanie kryzysu. „Przejście $\mathrm{z}$ rodziny do przedszkola stanowi istotną zmiane w życiu dziecka, które nieraz może stać się poważnym kryzysem" (Pomykało 1994, s. 636). Dziecko pozostawione samo w przedszkolu się obawia, jak pisze Beata Krzywda w swoim artykule 
Przedszkole - geneza i rodzaje lęków dziecięcych, że rodzice zapomną o nim. „Takim doznaniom towarzyszy przykry niepokój i przekonanie o tym, że na zawsze pozostanę w przedszkolu. Jest to tzw. lęk przed porzuceniem, który częściej występuje u dzieci z objawami zaburzonego funkcjonowania. Przyczyną wzmagająca poczucie tego lęku może być obawa, że mama mnie już nie kocha, bo kazała mi tu być, spóźnia się, żeby mnie stąd zabrać, a może w ogóle o mnie zapomniała" (Krzywda 2004, s. 3).

Dziecko w momencie przyjścia do przedszkola przechodzi od życia w rodzinie do funkcjonowania w grupie rówieśników, wśród których jego pozycja jest zupełnie inna. Ogromne znaczenie w tej kryzysowej sytuacji mają właśnie relacje z rówieśnikami. Lęk przed odrzuceniem przez grupę powoduje niemniej negatywne emocje i wyzwala niechęć do miejsca - przedszkola. Jeśli dziecko jest odrzucone, niezapraszane przez rówieśników do wspólnej zabawy, zaczyna izolować się od grupy, aby nie narazić się na osobistą porażkę. Tak przykre doświadczenia mogą prowadzić do różnego rodzaju lęków i poczucia osamotnienia. Pierwsze dni pobytu w przedszkolu wiążą się z całkowitą zmianą sytuacji życiowej dziecka, i jak pisze B. Krzywda, „Stymuluje ona sytuacje lękotwórcze, wyzwalające różne reakcje, takie jak: pobudzenie ruchowe, zachowania destrukcyjne, chaotyczne i nieadekwatne do sytuacji. W niektórych przypadkach są to także: zaburzenia nerwicowe (moczenie nocne, bóle brzucha i inne zaburzenia somatyczne), zachowania infantylne (znamienne dla wcześniejszej fazy rozwojowej), spadek odporności immunologicznej (częste infekcje i inne choroby) (Krzywda 2004, s. 5). Przedszkole jest więc także heterotopią dewiacji w znaczeniu Foucaulta. Wywód Magdaleny Archackiej na temat heterotopii szkoły łączy się w tym miejscu $\mathrm{z}$ analizowanym tematem i odnosi się w równym stopniu do przedszkola: „Zapleczem szkoły jest cały sztab specjalistów przygotowanych do określenia normy, zapobiegania dewiacji i patologii, obejmujący swym zasięgiem nie tylko szkołę, ale i rodzinę, a więc wykraczający daleko poza samą zlokalizowaną przestrzeń szkoły-instytucji. W dyskurs szkoły, placówki zamykającej osoby pozostające w stanie dewiacji i kryzysu w stosunku do społeczeństwa, zostaje włączony dyskurs wiedzy na temat populacji: jakie są potrzeby wieku dziecięcego? czym jest gotowość szkolna?” (Archacka 2016, s. 158).

\section{Druga zasada}

Drugą zasadą charakteryzującą heterotopię jest stała gotowość na redefinicję sposobu funkcjonowania lub wręcz formułowanie całkowicie odmiennej roli od tej, którą instytucja pełniła dotąd wobec społeczeństwa (Archacka 2016). Jarosław Barański (2016) pisze, że to społeczeństwo powołuje albo likwiduje heterotopię. „Stara się, dodajmy, niektóre podtrzymać, przede wszystkim ze względu na ów utopijny nośnik, który nadal pozostaje momentem świadomości kulturowej, a to oznacza, że heterotopie zaspokajają istotne potrzeby w społeczeństwie. [...] Jeśli te miejsca nie spełniają oczekiwań społecznych, podlegają żmudnej procedurze 
reform - wchodzą w stan permanentnego reformowania. Im więcej reformatorskich zapędów, tym więcej oczekiwań lokujemy w tych miejscach. Szkolnictwo wydaje się być przodujące w tym aspekcie" (Barański 2016, s. 31).

W Polsce większą uwagę na problematykę wychowania przedszkolnego zwrócono w okresie renesansu. Jan Amos Komeński dostrzegł potrzebę zorganizowania placówki wychowawczej dla dzieci w wieku przedszkolnym, w której dzieci w zespołach przygotowywałyby się do nauki. Przez lata dokonywały się przemiany w funkcji edukacji przedszkolnej, od historycznie najważniejszej - funkcji opiekuńczej, poprzez dominujące w późniejszych latach funkcje: dydaktyczną i wychowawczą, aż po współcześnie najważniejszą z nich, czyli wspomaganie rozwoju dziecka (Szymczyk 2012). Obecnie nadrzędnym „celem wychowania przedszkolnego jest wsparcie całościowego rozwoju dziecka. Wsparcie to realizowane jest przez proces opieki, wychowania i nauczania - uczenia się, co umożliwia dziecku odkrywanie własnych możliwości, sensu działania oraz gromadzenie doświadczeń na drodze prowadzącej do prawdy, dobra i piękna" (Dz.U. z 2017 roku, poz. 356). W koncepcji pedagogicznej Reggio Emilia dzieci stają się współorganizatorami codziennego życia w przedszkolu, to jest ich miejsce, które mogą urządzać i kształtować, wspierani przez nauczycieli i rodziców. Pedagogika Reggio podlega ciągłym przeobrażeniom w zależności od dostrzeganych potrzeb. W podejściu tym bowiem dobro dziecka jest zarówno punktem wyjścia, jak i celem wszelkich działań. „U podstaw koncepcji wczesnej edukacji u Reggio Emilia leży oparta na założeniach społecznego konstrukcjonizmu wizja dziecka: dziecka pełnego potencjału, którego źródłem jest dziecięca umiejętność dziwienia się; dziecka silnego i kompetentnego" (Bonar, Maj 2015, s. 45).

Współcześnie nastąpiła także reorientacja celów, jak podaje Tadeusz Lewowicki, „przez całe lata kształcenie orientowane było na wiadomości, umiejętności i wartości jako zasadniczy składnik postaw. Obecnie postawy coraz częściej wysuwane są na plan pierwszy, następnie są umiejętności, a na końcu dopiero - wiadomości” (Szymczyk 2012, s. 30, cyt. za: Lewowicki 1997, s. 29).

Wraz ze zmieniającym się społeczeństwem modyfikacji ulegają także relacje między przedszkolem a rodzicami dziecka, które do niego uczęszcza. Obecne relacje rodzic-przedszkole charakteryzują takie określenia, jak: partnerstwo, współudział, współodpowiedzialność, idea otwartych drzwi, aktywna obecność rodziców, rodzic w roli asystenta, wolontariat rodzicielski, czynny udział rodziny, pełnienie funkcji pomocniczych (Szymczyk 2012). Rodzic nie jest już tylko biernym obserwatorem życia swojego przedszkolaka, ale w pełni zaangażowanym organizatorem.

Obserwując historyczne zmiany funkcji przedszkola, dostrzegamy także ewaluację dotyczącą znaczenia nauczyciela. Pojęcie „nauczyciel” zmieniało się na przestrzeni wieków. Gdy w latach 70. XX wieku do przedszkoli wprowadzono dydaktykę, zmianie uległa nawet nazwa stanowiska, z wychowawczyni przedszkola na nauczyciela przedszkolnego (Szymczyk 2012). Zawsze jednak podstawową funkcją nauczyciela było uspołecznienie dzieci i przekazanie im dziedzictwa kulturowego, tak aby jak najlepiej przygotować je do funkcjonowania w społeczeństwie 
(Kwiatkowska 2008). Współcześnie dorosły nie jest już twórcą dziecka, ale jego przewodnikiem, partnerem w odkrywaniu otaczającej rzeczywistości oraz poznawaniu samego siebie (Nowak 167).

W tej skróconej historii wychowania przedszkolnego możemy zaobserwować, że wraz z ewoluującym społeczeństwem, jego priorytetowymi wartościami i potrzebami, zmianie ulegała także nadrzędna rola, jaką „przedszkole” stawiało sobie za cel.

\section{Trzecia zasada}

Michel Foucault omawiając trzecią zasadę heterotopii, twierdzi, że „jest zdolna zestawić w jednym prawdziwym miejscu kilka miejsc, kilka stron, które same w sobie są niekompatybilne" (Foucault 1984, s. 6). Foucault podaje tu przykład ogrodu, który podzielony jest na różne obszary, a rośliny znajdujące się w nim pochodzą z całego świata i bez interwencji człowieka tworzącego to miejsce nie miałyby prawa razem rosnąć.

Współczesne przedszkole także jest niezwykle różnorodne pod względem kulturowym i rasowym. Wynika to $\mathrm{z}$ wielokierunkowej migracji ludności, mieszania się nacji oraz samoistnego przenikania się kultur.

„Właściwie kulturowo zorganizowana grupa przedszkolna to miejsce, gdzie respektowana jest indywidualność, niwelowane są różnice, a skutki wcześniejszych doświadczeń dzieci są respektowane. To miejsce, w którym każde dziecko czuje się bezpiecznie, komfortowo, jest doceniane i chce się uczyć. Jednak każde dziecko z innej kultury wzbogaca społeczność przedszkolną. Wnosi nowy język, idee, umiejętności, wartości i przekonania. Im więcej dzieci poznają różnic między sobą i podobieństw, tym łatwiej będzie im się zrozumieć i razem funkcjonować" (Klim-Klimaszewska, Jagiełło 2013, s. 199).

Dzieci pochodzą z bardzo różnych środowisk, a ich myśli, sposoby komunikowania się, wartości i tradycje mogą znacznie się różnić. Można mówić nawet o kulturze rodzinnej (Klim-Klimaszewska, Jagiełło 2013). Młody człowiek „,samorzutnie naśladuje między innymi zwyczaje panujące $\mathrm{w}$ domu i w otoczeniu domowym, w którym przebywa niezależnie od tego, czy są one dobre, czy złe. Rodzinę określa się jako miniaturę społeczeństwa, w którym dziecko od najmłodszych lat uczy się przystosowania społecznego, przyswaja sobie i utrwala wzory zachowania osób mu najbliższych w danym momencie" (Pindera i in. 2006, s. 123). Przedszkole tworzy więc przestrzeń, która $\mathrm{w}$ jednym miejscu zestawia ze sobą różne wzorce postępowania, zwyczaje, wierzenia i praktyki.

Przedszkole to miejsce osobliwe także pod tym względem, że na każdym kroku następuje dystrybucja znaczeń, gestów, postaw. Zawiera w sobie przestrzeń różnorodnych działań: salę do nauki i plac zabaw, szatnię i gabinet pani dyrektor, toalety i stołówkę. Łączy miejsca właściwie niedające się połączyć. 


\section{Czwarta zasada}

Kolejną zasadą heterotopii jest to, że powinna być ona połączona z konkretnym odcinkiem czasu. Foucault mówi, że heterotopia połączona jest $\mathrm{z}$ „plastrami czasu” (Foucault 1984). „Wychowanie przedszkolne obejmuje dzieci od początku roku szkolnego w roku kalendarzowym, w którym dziecko kończy 3 lata, do końca roku szkolnego w roku kalendarzowym, w którym dziecko kończy 7 lat. W szczególnie uzasadnionych przypadkach wychowaniem przedszkolnym może także zostać objęte dziecko, które ukończyło 2,5 roku” (Dz.U. z 2015 roku, poz. 2156 ze zm.). Ten konkretny „kawałek” czasu ma znaczący wpływ na rolę, jaką pełni ta instytucja.

Rodzina jest zaś grupą społeczną, która najwcześniej oddziałuje na dziecko i stymuluje jego rozwój we wszystkich sferach. W domu rodzinnym dziecko zdobywa pierwsze doświadczenia związane z otaczającym go światem, poznaje normy i wzory zachowań, uczy się reakcji emocjonalnych w różnych sytuacjach, także trudnych i stwarzających poczucie zagrożenia (Krzywda 2004). W przedszkolu dziecko wkracza w inny niż znany mu dotąd świat. To nie tylko miejsce pełne nowych osób i przedmiotów, lecz także instytucja, w której spotyka się z systemem wymagań, oczekiwań, odpowiedzialności i samodzielności. Przedszkole staje się miejscem przemiany dla dziecka - kształtowania się osobowości oraz nabywania przez nie różnorakich doświadczeń i umiejętności. „Dzieci nie chodzą do przedszkola wyłącznie po to, żeby spędzać tam czas; ucząc się i bawiąc, zostają w określony sposób upodmiotowione: stają się dobrymi przedszkolakami i dziećmi. Dowiadują się, że pewne sposoby zachowania, umiejętności i zdolności są cenione, warte zdobycia i po prostu dobre, podczas gdy inne zasługują tylko na wykorzenienie" (Gawlicz 2008, s. 38, cyt. za: Foucault 1998, s. 180).

\section{Piąta zasada}

Piąta zasada heterotopii Foucaulta mówi, że: heterotopie zawsze zakładają system otwierania i zamykania, który zarówno je izoluje, jak i sprawia, że są przepuszczalne. Nie jest to więc miejsce swobodnie dostępne, jak w przypadku miejsc publicznych (Foucault 1984). Każdy może wejść do tej przestrzeni, ale w rzeczywistości jest to tylko złudzenie. Tak więc rodzice odprowadzający dzieci do przedszkola, uczestniczący w przedstawieniach, mogą sądzić, że wkraczają w „inną przestrzeń”, ponieważ przekraczają próg instytucji, lecz jest to jedynie ich złudne wrażenie. Wejście do przedszkola jest otwarte, lecz nie dla wszystkich. Każda jednostka musi spełnić pewne kryteria, aby móc być w tym miejscu. Zrytualizowana przestrzeń tworzy własne zwyczaje, przejścia związane z rozpoczęciem i zakończeniem kolejnych etapów bycia uczestnikiem, przynależnością do określonej grupy wiekowej. Rytuał inicjacyjny, przybierający formę pasowania na przedszkolaka, symbolizuje rozpoczęcie nowego etapu: „opuszczenie rodziny”, a w zamian zyskanie statusu „ucznia”. Przedszkole ma także własny system „otwierania i zamykania” w ciągu 
roku, który różni się od standardowego roku kalendarzowego, do którego odnosi się szersze społeczeństwo. Codzienność całej rodziny dziecka zostaje włączona w rytualną rzeczywistość heterotopii przedszkola - przestrzeni określonej lokalizacją miejsca, a jednak otwierającej swe granice daleko poza miejsce (Archacka 2016, s. 161).

\section{Szósta zasada}

„Wszystkiego, co naprawdę powinienem wiedzieć, nauczyłem się w przedszkolu o tym jak żyć, co robić, jak postępować, współżyć z innymi, patrzeć, odczuwać, myśleć, marzyć i wyobrażać sobie lepszy świat...” (Fulghum 1988).

Ostatnia cecha heterotopii polega na tym, że pełnią one funkcje w stosunku do całej pozostałej przestrzeni (Foucault 1984). Przedszkole to miejsce, gdzie dziecko rozwija umiejętności i nabywa ważne kompetencje, które wykorzysta w późniejszym życiu, to miejsce, które przygotowuje „idealnego" członka danej społeczności, stwarzając warunki umożliwiające mu potencjalny sukces $\mathrm{w}$ dalszym życiu. To, jaki „fundament” otrzyma dziecko w przedszkolu, decyduje często o tym, jaką przyszłość będzie na nim budować. „Pierwsze lata życia dziecka decydują o jego rozwoju i dalszych losach. Wtedy właśnie kształtują się możliwości intelektualne i rozwija się większość wrodzonych predyspozycji, w tym także zdolność uczenia się. Dlatego działania edukacyjne oraz szczególnie istotne na tym etapie oddziaływania wychowawcze, stymulowanie rozwoju intelektualnego i społecznego dziecka, przynoszą najlepsze rezultaty właśnie w okresie przedszkolnym. Jest to też najlepszy czas na zapobieganie ewentualnym trudnościom w nauce - niwelowanie dysharmonii rozwojowych, terapię zaburzeń, wyrównywanie zaniedbań środowiskowych. Postawy i umiejętności, które małe dzieci wynoszą z przedszkola, procentują w szkole lepszymi wynikami w nauce, a w dorosłym życiu lepszym funkcjonowaniem społecznym i zawodowym" (Podstawa programowa z komentarzami, s. 14).

Przedszkole sprawuje funkcję wychowawczą, kształcącą i opiekuńczą. Wspomaga dziecko we wszystkich rodzajach aktywności: społecznej, językowej, poznawczej, artystycznej, ruchowej i zdrowotnej. W przedszkolu znacznie częściej niż w domu rodzinnym dziecko ma okazję doświadczyć, że ludzie są różni, mówią różne rzeczy i różnie się zachowują. Sytuacje, w których istnieje rozbieżność między tym, co wie dziecko, a co wiedzą na dany temat inni, godzenia się z odmiennością poglądów i uzgadniania różnych punktów widzenia, są niezastąpionym motorem rozwoju zarówno poznawczego, jak i społecznego czy emocjonalnego. Zdaniem Stanisława Nieciuńskiego, „rozwój społeczny rozumiany jest jako wynik przezwyciężania sprzeczności, która leży między jednostką, a całościa społeczną, gdyż człowiek jest całością i jednocześnie częścią większych całości. Jako całość jest aktywnym, wewnętrznie wolnym i twórczym podmiotem, charakteryzuje go pewien stopień odrębności. Jako część spełnia określone wymogi istniejące w danej zbiorowości 
podlegając działaniom czynników zewnętrznych" (Pindera i in. 2006, s. 122, cyt. za: Łobocki 1979, s. 32).

\section{Słowo końcowe}

Można powiedzieć, że przedstawione podejście mieści się w paradygmacie interpretacji, iż każdy może znaleźć własną odpowiedź na pytanie: czy przedszkole jest „inną przestrzenią” Foucaulta. Miejsca i nie-miejsca przeciwstawiają się sobie jak słowa i pojęcia, które pozwalają je opisać. W konkretnej rzeczywistości dzisiejszego świata miejsca i przestrzenie, miejsca i nie-miejsca mieszają się ze sobą i wzajemnie się przenikają (Kurzynoga, za: Auge 2010).

Miejsce zawsze jest znaczące. Wszystko ma bowiem miejsce.

Gdzieś toczą się wydarzenia, gdzieś układają się sensy,

za których pośrednictwem pojmujemy rzeczywistość,

a w niej siebie, z mniej lub bardziej klarownym,

lecz zawsze obecnym poczuciem związku z miejscem.

(Mendel 2006, s. 21)

\section{Bibliografia}

Archacka M. (2016). Szkoła. Społeczna rola heterotopii. W: Gromysz J., Włodarczyk R. (red.). Utopia a edukacja, tom I o wyobrażeniach świata możliwego. Wrocław: Instytut Pedagogiki Uniwersytetu Wrocławskiego.

Auge M. (2010). Nie-miejsca. Wprowadzenie do antropologii hipernowoczesności. Warszawa: Wydawnictwo Naukowe PWN.

Barański J. (2016). Uwagi do heterotopii szkoły i jej utopijnej intencji. W: Gromysz J., Włodarczyk R. (red.). Utopia a edukacja tom I o wyobrażeniach świata możliwego. Wrocław: Instytut Pedagogiki Uniwersytetu Wrocławskiego.

Blair E. (2009). A further education college as a heterotopia. Journal Articles; „Reports - Descriptive”, vol. 14, nr 1, March 2009, s. 93-101.

Bonar J., Maj A. (2015). Przedszkola Reggio Emilia we Włoszech miejscem rozkwitu dziecięcego potencjału. „Problemy wczesnej edukacji”, nr 4 (31), s. 45.

Copik I. (2013). Pedagogika miejsca - kultura lokalna a kształtowanie się tożsamości współczesnego człowieka. „Pedagogika”, t. XXII, Prace Naukowe Akademii im. Jana Długosza w Częstochowie, s. 179-189.

Dmochowska H. (2013). Modyfikacja funkcji przedszkola wobec sytuacji rodzinnej dziecka. „Wychowanie w Rodzinie”, t. VIII (2/2013), s. 227-238.

Fulghum R. (1988). All I Really Need to Know I Learned in Kindergarten. New York: Villard Books. 
Foucalut M. (1984). Of Other Spaces: Utopias and Heterotopias. „Architecture/ Mouvement/Continuité”, October („Des Espace Autres”, March 1967, translated from the French by Jay Miskowiec).

Gadzinowska A. (2009). Społeczeństwo i rytuat: heterotopia bezdomności, Maria Mendel. Toruń 2007 [recenzja]. „Kultura i Edukacja”, nr 1, s. 156-161.

Gawlicz K. (2008). Konstruowanie nieudacznika: praktyki normalizacji i wykluczenia w przedszkolu. „Zeszyty Etnologii Wrocławskiej”, nr 1 (10), s. 37-54.

Klim-klimaszewska A., Jagiełło E. (2013). Nauczyciel przedszkola w społeczeństwie wielokulturowym. „Chowanna”, t. 2, s. 193-202.

Krzywda B. (2004). Przedszkole - geneza i rodzaje lęków dziecięcych. „Remedium”, nr $7 / 8$, s. 8-9.

Kurzynoga M. (2012). Heterotopia domu dziecka, czyli o miejscu bez miejsca. „Teraźniejszość-Człowiek-Edukacja”, nr 4 (60), s. 87-95.

Kwiatkowska H. (2008) Pedeutologia. Warszawa: Wydawnictwa Akademickie i Profesjonalne.

Mendel M. (2006). Pedagogika miejsca i animacja na miejsca wrażliwe. W: Mendel M. (red.). Pedagogika miejsca. Wrocław: Wydawnictwo Naukowe DSW.

Mendel M. (2017). Utopia jako edukacyjna interwencja. Od dekonstruowania heterotopii w narracjach do multikulturalizmu. Wrocław: Instytut Pedagogiki Uniwersytetu Wrocławskiego.

Nowak J. (2009). O nauczycielu przedszkola w świetle teorii i praktyki pedagogicznej. W: Kasaáčová B., Cabanová M. (red.). Učitel’v preprimárnej a primárnej edukácii. Teória, výskum, vývoj. Banská Bystrica, s. 156-176.

Ostrowicka H. (2010). Horyzont oczekiwań - z recepcji myśli Michela Foucault w badaniach pedagogicznych. „Teraźniejszość-Człowiek-Edukacja: Kwartalnik Myśli Społeczno-Pedagogicznej”, nr 3 (51), s. 7-23.

Pamuła-Behrens M. (2015). Wszystko zaczyna się w przedszkolu - nauka języka obcego dla dzieci, dostępny na: https://depot.ceon.pl/handle/123456789/6871 (otwarty: 26.03.2108).

Pindera P., Pindera M., Szames J. (2006). Zachowania społeczne dzieci w przedszkolu. „Nauczyciel i Szkoła”, nr 1-2 (30-31), s. 122-133.

Rozporządzenie Ministra Edukacji Narodowej z dnia 14 lutego 2017 roku w sprawie podstawy programowej wychowania przedszkolnego oraz podstawy programowej kształcenia ogólnego dla szkoły podstawowej, w tym dla uczniów $\mathrm{z}$ niepełnosprawnością intelektualną w stopniu umiarkowanym lub znacznym, kształcenia ogólnego dla branżowej szkoły I stopnia, kształcenia ogólnego dla szkoły specjalnej przysposabiającej do pracy oraz kształcenia ogólnego dla szkoły policealnej, Dz.U. z 2017 roku, poz. 365.

Szymczyk L. (2012). Przemiany $w$ teorii i praktyce wychowania przedszkolnego. „Nauczyciel i Szkoła”, nr 2 (52), s. 27-40. 


\title{
HETEROTOPIA OF KINDERGARTEN, ABOUT THE “NO- PLACE IN PLACE”
}

\begin{abstract}
There are places which create their own rituals and circumstances give them functions. The kindergarten seems to be such a place - "a different space". The object of my considerations, in which I applied the understanding of the specific kindergarten space as a "no-place in the place", are the six principles defining Foucault's heterotopy. Considering each of them, I refer to preschool as an institution which, apart from implementing its basic goals focused on care and supporting child's development, becomes a unique microcosm for every pupil.
\end{abstract}

Keywords: heterotopia, Michel Foucault, kindergarten.

Lidia Kurcińska - magister, absolwentka Akademii Pedagogiki Specjalnej w Warszawie. Nauczyciel dyplomowany. Pedagog specjalny, pedagog szkolny w Szkole Podstawowej nr 5 w Piasecznie. Nauczyciel terapii pedagogicznej w ZSRCKU w Piasecznie. Obecne jej zainteresowania naukowe koncentrują się na zagadnieniach związanych z pedagogiką społeczną (pedagogiką miejsca) i tym, w jaki sposób miejsce wpływa na kształtowanie się tożsamości młodego człowieka. Adres e-mailowy: lidia.kurcinska@gmail.com. 